\title{
Author Correction: Simulating nephron ion transport function using activated wafer electrodeionization
}

Christa N. Hestekin, Jamie A. Hestekin, Sadia Paracha, Grace Morrison, Efecan Pakkaner (D, John Moore, Leticia Santos de Souza, Sam Stephens (10, Catey Atchley \& Ira Kurtz

Correction to: Communications Materials https://doi.org/10.1038/s43246-020-0016-3, published online 27 April 2020.

Figure 1 in the original published version of this article was incorrectly supplied in black and white. It has now been replaced with a color version in both the HTML and PDF versions of the article.

Published online: 14 May 2020

\footnotetext{
(c) Open Access This article is licensed under a Creative Commons Attribution 4.0 International License, which permits use, sharing, adaptation, distribution and reproduction in any medium or format, as long as you give appropriate credit to the original author(s) and the source, provide a link to the Creative Commons license, and indicate if changes were made. The images or other third party material in this article are included in the article's Creative Commons license, unless indicated otherwise in a credit line to the material. If material is not included in the article's Creative Commons license and your intended use is not permitted by statutory regulation or exceeds the permitted use, you will need to obtain permission directly from the copyright holder. To view a copy of this license, visit http://creativecommons.org/licenses/by/4.0/.
}

(C) The Author(s) 2020 